\title{
PESOS Y MEDIDAS
}

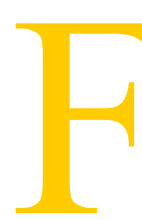

rancisco Laporta ni quita ni pone rey, pero critica dos argumentos míos con los que intentaba mostrar que la «ética de la responsabilidad» se justifica con falacias. Aquí estableceré la impertinencia de su crítica respecto de mis argumentos.

1. Laporta rechaza el primero de ellos diciendo que ahí la fuerza causal de la tortura resulta inventada y que la «ética de la responsabilidad» sólo pretende entrar en juego cuando se da la existencia de relaciones causales entre Tortura y Evitación del mal.

Con ello Laporta establece un modelo argumental distinto al mío. En mi modelo, imaginado para una deliberación moral previa a la acción, el universo discursivo se extiende desde la «posibilidad de torturar» hasta la «posible evitación del mal», y se muestra que entre tales extremos no se establecen relaciones que justifiquen una «decisión de torturar». El modelo de Laporta sólo podría entrar en juego para alegar una dudosa excusa a posteriori de la tortura, pues parte de la existencia de una relación causal entre la «acción de torturar» -interpreto así su uso de «tortura» a secas, ya que la pasión o padecimiento sólo es vista por Laporta como hecho consecuente, al igual que la confesión, y no como acto moral- y la «evitación de un mal» distinto de la primera.

Sólo cabe establecer la existencia de la relación causal de Laporta post festum, si en este caso puede decirse así. Pues sufriendo tortura una persona puede hablar, puede callar (como sabemos los lectores de La Question), y también puede morir, enloquecer o confesarse autora de la muerte de Manolete o del crimen de Cuenca.

2. Laporta opina que en mi segundo argumento he incurrido en una petitio principi al exigir que los principios de la «acción según principios» sean «buenos». Y establece un cuadro de posibilidades que relaciona «principios» y «consecuencias» para sugerir a) que sugiero que los principios éticos siempre producen buenas consecuencias y $b$ ) que excluyo la posibilidad de que una acción contra principios sea causa de buenas consecuencias. 
Laporta y los éticos de la responsabilidad hablan de consecuencias de la acción y yo de sus resultados. Von Wright formalizó el punto hace años. El resultado de una acción u omisión es el estado del mundo que no hubiera podido darse sin ella; las consecuencias incluyen las acciones u omisiones ulteriores del mismo agente o de otros y la posible transformación autónoma del estado del mundo a partir del resultado. Atribuir consecuencias es siempre muy impreciso: a la acción de Jesús de Nazaret se podría atribuir así consecuencias como la Inquisición, la vacuna o los Grandes Expresos Europeos.

No me parece pensable que una acción según buenos principios pueda ser causa de un resultado malo. Asunto distinto son los dilemas trágicos, tan cercanos y corrientes que hasta los penalistas les echan un resignado manto común, la «legítima defensa». Situaciones perentorias en que ningún principio moral basta y al ser humano se le exige inventar un comportamiento moral, precisamente suyo, porque el mundo externo exhibe cruelmente sus antagonismos. De ahí palabras sustantivas como «sacrificio».

$\mathrm{Su}$ conversión en verbos transitivos es ambigua. ¿Es un comportamiento moral sacrificar a otros? La respuesta depende de los principios que se sostengan. El almirante Carrero Blanco afirmaba que prefería morir en un holocausto nuclear a contemplar el fin de la civilización occidental y cristiana. El singular era aquí sólo de dicto. El señor González Márquez lo utilizaba de re al preferir morir apuñalado en el metro de Nueva York a tener que vivir en Moscú. De dicto o con metáfora de re, dudo que alguna de estas preferencias morales manifestadas por políticos profesionales suscite adhesión moral en la gente de metro. Aun discrepando de la separación estricta operada por Maquiavelo entre ética y política, la considero menos engañosa que el doble-pensar moral del realismo realista categorizado por Weber como «ética de la responsabilidad».

\section{DOXA 5 (1988)}

